International Journal of Current Advanced Research

ISSN: O: 2319-6475, ISSN: P: 2319 - 6505, Impact Factor: SJIF: 5.995

Available Online at www.journalijcar.org

Volume 6; Issue 3; March 2017; Page No. 2759-2767

DOI: http://dx.doi.org/10.24327/ijcar.2017.2767.0100

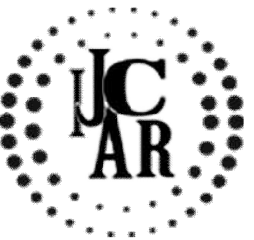

Research Article

\title{
VARIABILITY OF COWPEA (VIGNA UNGUICULATA L.) NODULATION: WHAT EFFICIENCY IN USE OF THE RHIZOBIAL SYMBIOSIS FOR PLANT GROWTH UNDER ZAÏ CULTIVATION IN SUB-SAHARAN AGRO-ECOSYSTEM OF BURKINA FASO?
}

\author{
*Koulibi Fidèle Zongo ${ }^{1}$., Mohamed Traoré2., Edmond Hien ${ }^{1,3}$., \\ Didier Blavet ${ }^{3}$., Cathy Clermont-Dauphin ${ }^{3}$ and Jean-Jacques Drevon ${ }^{4}$
}

1Université Ouaga I Pr Joseph KI-ZERBO, UFR-SVT, 03 BP 7021, Ouagadougou 03, Burkina Faso

${ }^{2}$ Ecole Normale Supérieure de Bamako, BP 241, Bamako, Mali

${ }^{3}$ Institut de Recherche pour le Développement, UMR Ecologie Fonctionnelle \& Biogéochimie des Sols et Agroécosystèmes,

INRA-IRD-CIRAD-SupAgro. Place Pierre Viala, 34060 Montpellier, France

4Institut National de la Recherche Agronomique, UMR Ecologie Fonctionnelle \& Biogéochimie des Sols et Agroécosystèmes,

INRA-IRD-CIRAD-SupAgro. Place Pierre Viala, 34060 Montpellier, France

A R T I C L E I N F O

Article History:

Received $18^{\text {th }}$ December, 2016

Received in revised form $16^{\text {th }}$ January, 2017

Accepted $26^{\text {th }}$ February, 2017

Published online $28^{\text {th }}$ March, 2017

Key words:

Cowpea, organic substrates, phosphorus bioavailability, rhizobia, symbiotic nitrogen fixation.

\begin{abstract}
A B S T R A C T
Sorghum-cowpea intercropping is the most common cropping system in the Sub-Saharan region of Burkina Faso where soil fertility is low. One of its specificity is the sowing of the both species in the same zaï holes. This study analyzes the variability of nodulation and growth of cowpea, and their relations according to organic fertilization, farmer's field, and years. Two treatments with and without organic substrates, namely ZF and ZS, respectively, were compared in 12 field trials established during years 2012, 2013 and 16 field tests during 2014, in 3 villages in the north of Burkina. The results showed that the nodulation and shoot growth of cowpea, varied among sites and years, and were higher under ZF than ZS, whatever the year. The nodulation variability depended upon organic substrate $\mathrm{P}$ and $\mathrm{N}$ in 2014 under $\mathrm{ZF}$, and upon soil $\mathrm{P}$ bio-availability in 2012, 2013 and 2014 under ZS. Under ZS, the mean efficiency of individual nodule to support shoot dry weight was $0.6 \pm 0.2$ and $4.0 \pm 1.6 \mathrm{~g}$ shoot dry weight per nodule in 2014 and 2012, respectively. In 2013, there was no significant correlation between growth and nodulation, which could be explained by low average rainfall. In 2014 under ZS, the high efficiency in use of the rhizobial symbiosis of cowpea plant was $128.5 \pm 35.4 \mathrm{~g}$ shoot dry weight per $\mathrm{g}$ nodule dry weight and the $\mathrm{N}$ derived from nodule $\mathrm{N} 2$ fixation could be estimated as 510.9 $\pm 127.1 \mathrm{mg} \mathrm{N}$ per g nodule dry weight. It is concluded that the measurements of nodulation and growth of cowpea at flowering stage may contribute to optimize the organic fertilization of cowpea in zai intercropping with sorghum and the subsequent improvement of crop yields in Northern-Burkina Faso.
\end{abstract}

Copyright $\mathrm{C} 2017$ Koulibi Fidèle Zongo. This is an open access article distributed under the Creative Commons Attribution License, which permits unrestricted use, distribution, and reproduction in any medium, provided the original work is properly cited.

\section{INTRODUCTION}

In Sub-Saharan Africa, sorghum-cowpea intercropping is the most frequent cropping system. Both species are generally sown in the same zaï holes. The zaï sowing is a farmers' innovation to obtain a production from their most degraded fields. The advantages of this practice are considered the concentration in the zaï holes of both rainwater around the seedlings and small amount of organic fertilizer available in the farms (Roose 2004; Zougmoré et al. 2004; Sawadogo et al. 2008; Hien et al. 2010; Bayala et al. 2012; Somé et al. 2015).

*Corresponding author: Koulibi Fidèle Zongo

Université Ouaga I Pr Joseph KI-ZERBO, UFR-SVT, 03 BP

7021, Ouagadougou 03, Burkina Faso
In view of the high proximity of the seedlings of both species of each other, another advantage of the zail sowing could be the increase in positive interactions between the cereal and the legume, in particular for the processes of $\mathrm{N}_{2}$ fixation by the legume and $\mathrm{N}$ transfer to the cereal by either rhizo-deposition and rhizo-decomposition (Fustec et al. 2011; Laberge et al. 2011). However, few information exist on the nodulation of cowpea and its efficiency for the crop growth in the farmers' fields under zaï sowing in Sub-Saharan Africa.

Several studies in semi-arid areas have quantified biological nitrogen fixation by cowpea root-nodules (Singh and Usha 2003; Oroko, 2010; de Freitas et al. 2012). Other studies have examined the effects induced by cowpea on the residual nitrogen of soils (Bationo et Ntare 2000; Bationo et al. 2002; Bado et al. 2006). In addition, the effects of organic, mineral 
or organo-mineral inputs for increasing nodulation, shoot and root dry weight mineral acquisition of cowpea have been documented (Singh and Usha, 2003; Chemining'wa et al. 2007; Oroko 2010; Santos et al. 2011; Assuming-Brempong et al. 2013; Kouyaté et al. 2014). However, these studies were generally conducted in research station or a single farmer field, or greenhouse with plastic pots in Burkina (Bado et al., 2006), in Kenya (Chemining'wa et al., 2007), in Nigeria (Oroko, 2010; Egbe et al., 2010), in Ghana (AssumingBrempong et al., 2013), and in Mali (Kouyaté et al., 2014).

However, in Sub-Saharan Africa, the variability of farmers' fields has not been taken into account in the evaluation of nodulation and biomass production, whereas thus soils diversity should be taken into account in addition to climate variability when suggest technical practices for improving crop yields. Thus, assessment of nitrogen-fixing nodules and their contribution to the growth of cowpea is needed on farmers' fields. Within this framework, this study is aimed at analyzing the variability of nodule numbers and dry weight of cowpea, and the efficiency of nodulation and $\mathrm{N}$ derived from N2 fixation for cowpea plant growth by examining relational models between these parameters.

\section{MATERIALS AND METHODS}

\section{Experimental site}

The study was conducted in three villages in the Northern region of Burkina (Fig. 1), namely Pougyango $\left(12^{\circ} 58^{\prime} \mathrm{N}, 2^{\circ}\right.$ $\left.08^{\prime} \mathrm{W}\right)$, Zindiguéssé $\left(13^{\circ} 16^{\prime} \mathrm{N}, 2^{\circ} 20^{\prime} \mathrm{W}\right)$ and Soumyaga $\left(13^{\circ}\right.$ $\left.30^{\prime} \mathrm{N}, 2^{\circ} 24^{\prime} \mathrm{W}\right)$.

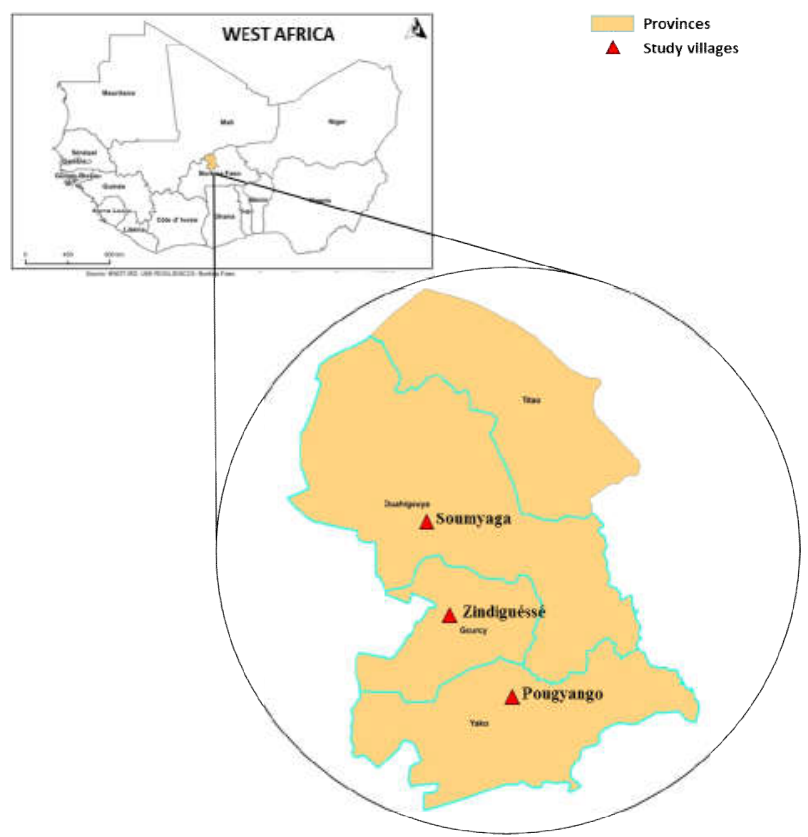

Fig 1 Map of the northern region of Burkina Faso and localization of study villages.

The three villages have been considered as representative of the diversity of regional soil and climate conditions. The climate is Sudano-Sahelian type, characterized by the alternation of a long dry season from October to May and a short rainy season from May to September when is concentrating $90 \%$ of the annual rainfall. Over the period 2000-2014, annual rainfall varied from 500 to $900 \mathrm{~mm}_{\text {year }}{ }^{-1}$ with an average of $715 \pm 108 \mathrm{~mm} \mathrm{year}^{-1}$ (Fig. 2A). The highest monthly temperatures of $35 \pm 5^{\circ} \mathrm{C}$ occur during April and May and the lowest of $25 \pm 4^{\circ} \mathrm{C}$ during December and January (Fig. 2B).

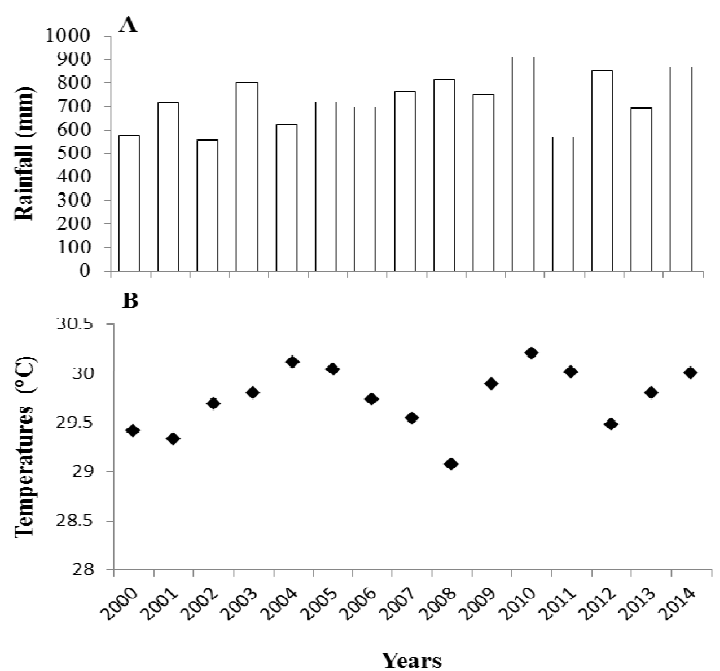

Fig. 2 Averages of rainfall (A) and temperature (B) between 2000 to 2014 in Northern region of Burkina Faso

Soil types are mainly epipetric plinthosols, endo-petroplinthic and hypogleyic lixisols (FAO, 2014). They are subject to strong water erosion because of their physiographic position and lack of vegetation cover. Physically, they are mostly gravelly with sandy loam to clay texture in depth. Chemically, nitrogen and phosphorus are deficient, $\mathrm{pH}$ is acidic and the concentration of organic matter is often below 1\% (FAO, 2000). Natural vegetation is formed by tiger bush, shrub and tree savannas (Guinko, 1998).

\section{Experimental design and crop husbandry}

Twelve farmers' fields under zaï cultivation were selected in 2012, 2013 and 16 multi-location test in 2014. In each field two treatments were compared: simple zaï without organic substrate (ZS) and zaï with $0.3 \mathrm{~kg}$ dry matter of organic substrate (ZF) per zaï hole, equivalent to $9 \mathrm{t} \mathrm{ha}^{-1}$. The organic substrate was a mixture of livestock dung, crop and household residues stocked in pits during the dry season, from November to May. It was applied in zaï hole before sowing, from May to early June. Its characteristics per village and years are presented in Table 1.

In 2012 and 2013 a randomized block design with 5 replicates was used in each field, whereas in 2014, each field was treated as a block containing the pair of treatments with no intra-field replication designated by multi-location test. In practice, we designed 5 agronomic blocks in 2012 and 2013, and one of these blocks was maintained in 2014. Elementary plots were $25 \mathrm{~m}^{2}$. Each plot contained 7 rows of 11 zaï holes per row, spaced $0.40 \mathrm{~m}$ apart on the rows and $0.80 \mathrm{~m}$ between rows. The rows were perpendicular to the slope of the elementary plots. In 2012, all treatments were sown with sorghum and cowpea intercropping, whereas in 2013 and 2014, a split consisted of 35 zaï holes with sorghum compared to 42 with cowpea and sorghum in intercropping.

In 2012 and 2013, field's trials were named P1, P2, P3, P4 in Pougyango, Z1, Z2, Z3, Z4 in Zindiguéssé and S1, S2, S3, S4 in Soumyaga. These names respectively use the first letter of the village plus additional number following numerical order. 

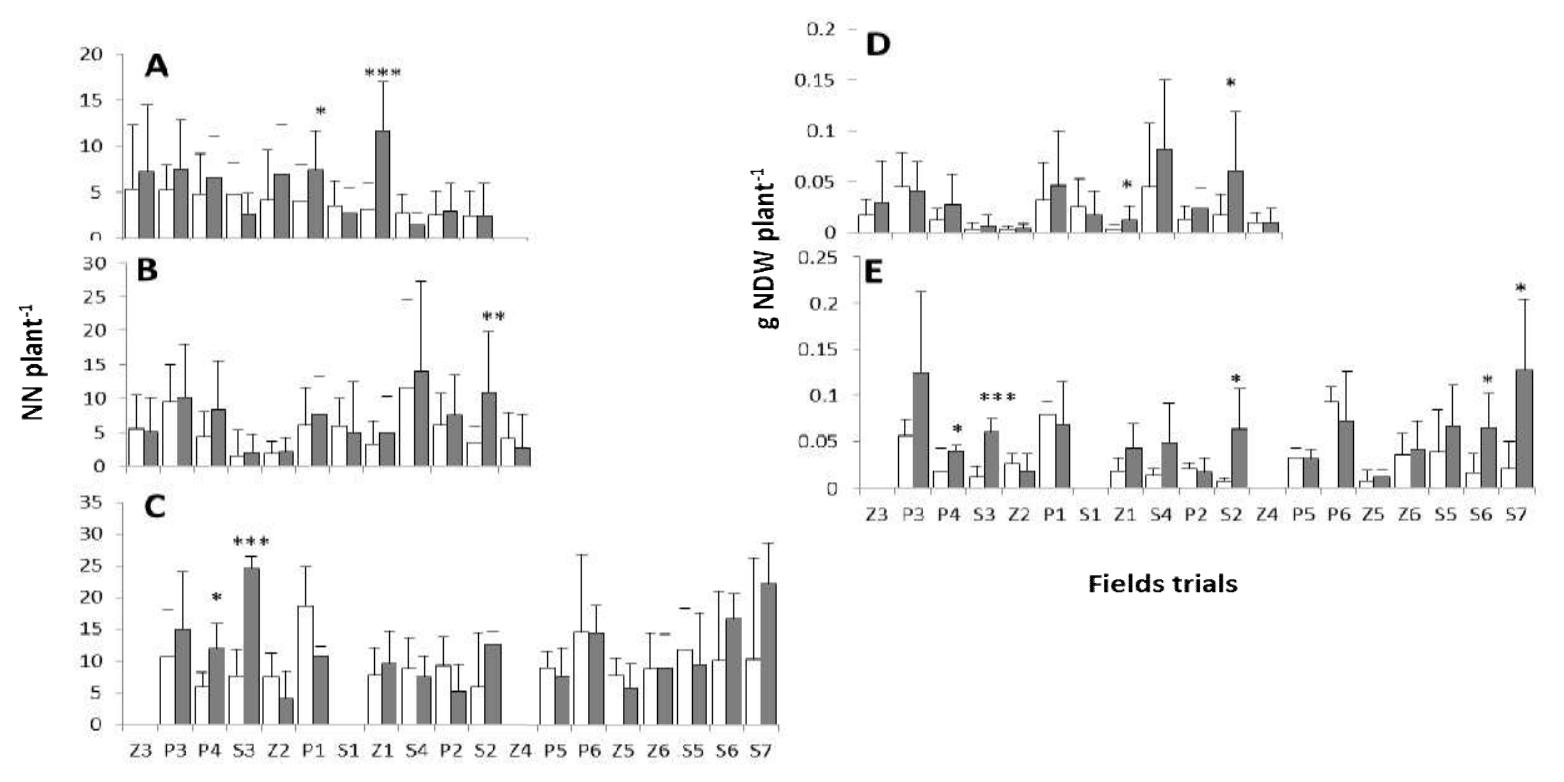

Fields trials

Fig. 3 Variations of nodules numbers (NN) in 2012 (A), 2013 (B), 2014 (C) and nodules dry weight (NDW) of cowpea plant in 2013 (A) and 2014 (B) under simple zaï $(\square)$ and zaï + organics substrates $(\square)$. Data are means \pm SD of 15 plants of cowpea in 2012 and 2013 , and 5 in 2014 by treatment per field trials harvested at flowering stage. $* * *, * * *$ indicate that the differences between means per treatment are significantly higher in the same field trial at probability $<0.05,<0.01$ and $<0.001$, respectively according to Tukey HSD tests.

In 2014, multi locations tests were designated P1, P2, P3, P4, P5, P6 in Pougyango, Z1, Z2, Z5, Z6 in Zindiguéssé and S2, S3, S4, S5, S6, S7 in Soumyaga. During 2014, Z3, Z4 and S1 fields trials were rejected because the lack of weed control and fields trials management in 2013. The supplementary number added to new multi-locations tests in 2014 followed the numerical order of all fields trials previously installed in 2012 and 2013 in each village. Homogeneous block per field's trials of 2012 and 2013 was chosen for multi-locations tests in 2014. The cultivars were Sariasso 14 in 2012 and Kapelga in 2013 and 2014 for sorghum, and KVX396-4-5-2D for cowpea whatever the year as recommended by the Institute of Environment and Agricultural Research (INERA). After thinning, 2 seedlings of cowpea and 2 of sorghum were left in the same zaï hole. Two weedings per year were managed by the farmers according to their own practice.

\section{Data collection}

Nodules number (NN) and shoot dry weight (SDW) of cowpea plants were measured in 2012, 2013 and 2014. The measurement of nodules dry weight (NDW) was added in 2013 and 2014. These data were collected at flowering stage, when $50 \%$ of the stand reached this stage which was approximately 45 days after sowing. They were based on a sample of 15 cowpea plants per treatment, collected in 3 holes x 5 blocks in each field trial of 2012 and 2013, and a sample of 5 cowpea plants per treatment, collected in 3 holes $\times 1$ block in each field of 2014. The cowpea roots were washed gently to remove the adhering soil, enabling the detachment of nodules. Nodules were separated from the roots, counted, and weighed after drying on a filter paper in the open air until constant weight. Shoots were separated from roots at the cotyledonary node, and then weighed after $48 \mathrm{~h}$ at $70{ }^{\circ} \mathrm{C}$ in oven.

\section{Plant chemical analyses}

$\mathrm{N}$ concentration of the shoot was determined by the CHN method with NA-2000 micro-analyzer. P concentration was determined by the molybdovanadophosphoric acid spectrophotometric method (Kitson and Mellon, 1944). N and $\mathrm{P}$ contents per plants were calculated by multiplying $\mathrm{N}$ and $\mathrm{P}$ concentration in the composite sample of dry shoots after grinding to $2 \mathrm{~mm}$, by the corresponding shoot dry weight.

\section{Statistical analysis}

Graphics and standard deviation (SD) were performed with Excel 2007. All data collected were subjected to one-way analysis of variance (ANOVA) using the R software (2.14.1). The mean differences were compared by the Tukey's HSD test at $5 \%$ probability. The relationship between parameters was tested by regression analysis with $\mathrm{R}$ software (2.14.1).

\section{RESULTS}

\section{Nodulation}

Data in Table 2 show nodules number (NN) and nodules dry weight (NDW) under simple zaï (ZS) and zaï + organic substrate (ZF) for the field trials in 2012, 2013 and 2014. From the data set, the means of NN per plant (NN plant ${ }^{-1}$ ) of cowpea intercropped with sorghum in 2012, 2013 and 2014 was significantly increased by ZF compared to ZS (Table 2). For each treatment, overall NN plant ${ }^{-1}$ of cowpea was almost similar in 2012 and 2013 (Table 2). The means of nodules dry weight per plant (NDW plant ${ }^{-1}$ ) of cowpea was highly increased by ZF by $+38 \%$ and $+46 \%$ respectively in 2013 and 2014 (Table 2).

For spatial variation in 2012, NN plant $^{-1}$ varied, though significantly from $1.5 \pm 1.2$ in $\mathrm{S} 4$ to $11.7 \pm 5.3$ in $\mathrm{Z} 1$ under $\mathrm{ZF}$, and not significantly from $2.5 \pm 2.7$ in $\mathrm{S} 2$ to $5.3 \pm 6.9$ in $\mathrm{Z3}$ under ZS (Fig. 3A). By comparison to ZS, the effect of ZF on $\mathrm{NN}$ varied from $-84 \%$ in $\mathrm{S} 3$ to $+73 \%$ in $\mathrm{Z} 1$. The increase 
Table 1 Characteristics of organic substrates

\begin{tabular}{|c|c|c|c|c|c|c|c|c|c|}
\hline Organic substrates & Pougyango & Zindiguéssé & Soumyaga & Pougyango & Zindiguéssé & Soumyaga & Pougyango & Zindiguéssé & Soumyaga \\
\hline characteristics & & 2012 & & & 2013 & & & 2014 & \\
\hline Moisture (\%) & 30 & 30 & 30 & 4 & 4 & 23 & 51 & 37 & 43 \\
\hline Fine fraction $(\%)$ & 72.1 & 85.6 & 88.0 & 69.9 & 82.3 & 83.0 & 77.4 & 73.2 & 81.1 \\
\hline Plant residues (\%) & 0.0 & 1.3 & 10.5 & 0.7 & 0.6 & 1.8 & 0.2 & 1.6 & 1.5 \\
\hline Mineral size (\%) & 27.9 & 13.1 & 0.5 & 29.4 & 17.1 & 15.2 & 22.4 & 25.2 & 17.4 \\
\hline Total C $\left(\mathrm{m} \mathrm{g}^{-1}\right)$ & 129.5 & 53.2 & 167.5 & 493 & 495.1 & 444.5 & 107.3 & 116.4 & 109.8 \\
\hline Total N (mg g $\left.{ }^{-1}\right)$ & 7.3 & 2.8 & 6.7 & 26.9 & 24.5 & 33 & 10.3 & 11.7 & 10.8 \\
\hline $\mathrm{C} / \mathrm{N}$ ratio & 17.7 & 19 & 25 & 18.3 & 20.2 & 13.5 & 10.4 & 9.9 & 10.1 \\
\hline $\mathrm{N} / \mathrm{P}$ ratio & 9.1 & 1.6 & 5.6 & 11.7 & 15.3 & 20.6 & 6.9 & 6.5 & 6.4 \\
\hline
\end{tabular}

Table 2 Means of nodules numbers, nodule and shoot dry weight of cowpea plant harvested at flowering stage. Data are means and standard deviations of nodule number, nodule dry weight and shoot dry weight of cowpea.

\begin{tabular}{|c|c|c|c|c|c|c|c|c|}
\hline \multirow{2}{*}{$\begin{array}{c}\text { Cowpea plant parameters } \\
\text { Years }\end{array}$} & \multicolumn{3}{|c|}{ NN plant ${ }^{-1}$} & \multicolumn{2}{|c|}{ mg NDW plant $^{-1}$} & \multicolumn{3}{|c|}{ g SDW plant $^{-1}$} \\
\hline & 2012 & 2013 & 2014 & 2013 & 2014 & 2012 & 2013 & 2014 \\
\hline \multicolumn{9}{|l|}{ Treatment effect } \\
\hline $\mathrm{ZS}$ & $3.6 \pm 3.9 \mathrm{~b}$ & $5.3 \pm 5.9 \mathrm{a}$ & $9.66 \pm 5.4 \mathrm{a}$ & $19.2 \pm 29.1 b$ & $31.2 \pm 29.9 b$ & $19.9 \pm 13.2 b$ & $5.9 \pm 5.8 b$ & $5.8 \pm 5.5 b$ \\
\hline $\mathrm{ZF}$ & $4.9 \pm 5.2 \mathrm{a}$ & $6.7 \pm 7.7 \mathrm{a}$ & $11.7 \pm 8.7 \mathrm{a}$ & $30.3 \pm 41.8 \mathrm{a}$ & $56.3 \pm 49.9 a$ & $26.2 \pm 16.9 \mathrm{a}$ & $11.9 \pm 11.7 \mathrm{a}$ & $15.9 \pm 12.1 \mathrm{a}$ \\
\hline $\mathrm{P}$ & $0.003 * *$ & $0.06 \mathrm{~ns}$ & $0.08 \mathrm{~ns}$ & $0.004 * *$ & $<0.001 * * *$ & $<0.001 * * *$ & $<0.001 * * *$ & $<0.001 * * *$ \\
\hline \multicolumn{9}{|l|}{ Interaction $\mathrm{ZS} x$ village } \\
\hline Pougyango & $4.2 \pm 3.5 \mathrm{a}$ & $6.1 \pm 5.1 \mathrm{a}$ & $11.3 \pm 7,0 \mathrm{a}$ & $25.9 \pm 28.8 \mathrm{a}$ & $49.9 \pm 37.5 b$ & $25.9 \pm 13.1 \mathrm{a}$ & $4.1 \pm 4,5 b$ & $8.5 \pm 7.3 \mathrm{a}$ \\
\hline Zindiguésé & $3.2 \pm 2.8 \mathrm{a}$ & $3.7 \pm 3.8 b$ & $7.9 \pm 2,9 \mathrm{a}$ & $8.4 \pm 11.3 b$ & $22.2 \pm 17.1 \mathrm{a}$ & $13.5 \pm 10.1 \mathrm{~b}$ & $5.7 \pm 5,8 b$ & $3.8 \pm 2.0 \mathrm{~b}$ \\
\hline Soumyaga & $3.4 \pm 4.9 \mathrm{a}$ & $5.6 \pm 7.9 \mathrm{ab}$ & $9.1 \pm 4,5 \mathrm{a}$ & $23.3 \pm 37.9 a$ & $18.4 \pm 15.9 a$ & $20.5 \pm 13.4 b$ & $8.1 \pm 6,17 \mathrm{a}$ & $4.2 \pm 3.6 \mathrm{~b}$ \\
\hline $\mathrm{P}(\mathrm{ZS})$ & $0.45 \mathrm{~ns}$ & $0.03 *$ & $0.08 \mathrm{~ns}$ & $0.002 * *$ & $<0.001 * * *$ & $0.003 * *$ & $<0.001 * * *$ & $0.002 * *$ \\
\hline \multicolumn{9}{|l|}{ Interaction $\mathrm{ZF} x$ village } \\
\hline Pougyango & $6.1 \pm 4.6 b$ & $8.4 \pm 6.6 \mathrm{a}$ & $10.8 \pm 7.1 \mathrm{ab}$ & $34.7 \pm 35.9 b$ & $59.0 \pm 55.5 \mathrm{ab}$ & $26.8 \pm 15.5 \mathrm{a}$ & $4.8 \pm 6,01 \mathrm{~b}$ & $20.9 \pm 13.6 \mathrm{a}$ \\
\hline Zindiguésé & $6.5 \pm 2.6 \mathrm{a}$ & $3.7 \pm 4.6 b$ & $6.8 \pm 4.2 \mathrm{~b}$ & $14.1 \pm 24.4 \mathrm{a}$ & $30.5 \pm 30.1 b$ & $25.0 \pm 16.2 \mathrm{a}$ & $14.4 \pm 10,25 \mathrm{a}$ & $12.5 \pm 6.8 \mathrm{~b}$ \\
\hline Soumyaga & $2.3 \pm 6.6 \mathrm{c}$ & $7.9 \pm 9.9 \mathrm{a}$ & $15.7 \pm 10.5 \mathrm{a}$ & $42.1 \pm 54.7 b$ & $70.8 \pm 49.2 \mathrm{a}$ & $26.9 \pm 19,1 \mathrm{a}$ & $16.7 \pm 14,02 \mathrm{a}$ & $13.3 \pm 11.9 \mathrm{~b}$ \\
\hline $\mathrm{P}(\mathrm{ZF})$ & $<0.001 * * *$ & $<0.001 * * *$ & $<0.001 * * *$ & $<0.001 * * *$ & $0.02 *$ & $0.06 \mathrm{~ns}$ & $<0.001 * * *$ & $0.02 *$ \\
\hline Interaction treatment $\mathrm{x}$ field trials & $<0.001 * * *$ & $0.18 \mathrm{~ns}$ & $0.003 * *$ & $0.003 * *$ & $<0.001 * * *$ & $<0.001 * * *$ & $<0.001 * * *$ & $<0.001 * * *$ \\
\hline
\end{tabular}

$\mathrm{P}=$ Probability of ANOVA variance test at $5 \%$ level of significance; $* * *, * * *$ indicate that the differences between means were significant at $\mathrm{P}<0.05, \mathrm{P}<0.01$ and $\mathrm{P}<0.001$, respectively according to Tukey multiple range tests. The means affected by the same letter in the same column are not significantly different. ZS $=$ simple zaï; ZF $=$ zaï + organic substrate; NN = nodules numbers; NDW = Nodule dry weight; SDW $=$ Shoot dry weight.

NN was significant only for 2 among 12 field trials P1 and Z1 (Fig. 3A). Comparing the 3 villages, NN plant ${ }^{-1}$ was significantly higher in Zindiguéssé than in Pougyango and Soumyaga, but only under ZF treatment (Table 2).

In 2013, $\mathrm{NN}_{\text {plant }}{ }^{-1}$ varied significantly from $2.1 \pm 2.7$ in S3 to $11.6 \pm 12.9$ in $\mathrm{S} 4$ under $\mathrm{ZS}$ and from $2.1 \pm 2.7$ in $\mathrm{S} 3$ to $13.9 \pm 13.4$ in $\mathrm{S} 4$ under ZF (Fig. 3B). By comparison to ZS, the effect of $\mathrm{ZF}$ on $\mathrm{NN}$ plant $^{-1}$ varied from $-49 \%$ in $\mathrm{Z} 4$ to $+67 \%$ in $\mathrm{S} 2$, though the increase of $\mathrm{NN}_{\text {plant }}{ }^{-1}$ was significant only in S2. NN plant ${ }^{-1}$ was significantly lower in Zindiguéssé than in Pougyango under ZS, and in Pougyango and Soumyaga under ZF (Table 2).

The nodule dry weight (NDW) per plant significantly varied from $3.3 \pm 3.3 \mathrm{mg}$ to $46.0 \pm 61.9 \mathrm{mg} \mathrm{NDW} \mathrm{plant}^{-1}$ in $\mathrm{Z} 2$ and $\mathrm{S} 4$, respectively under ZS, and from $4.1 \pm 4.3$ to $82.8 \pm 66.9$ mg NDW plant ${ }^{-1}$ in $Z 2$ and S4, respectively under ZF (Fig. 3D). By comparison to $\mathrm{ZS}$, the effect of $\mathrm{ZF}$ varied from $-48 \%$ in $\mathrm{S} 1$ to $+72 \%$ in $\mathrm{Z} 1$. NDW plant ${ }^{-1}$ significantly increased only in Z1 and S2 (Fig. 3D). NDW plant ${ }^{-1}$ was significantly lower in Zindiguésé than in Pougyango and in Soumyaga whatever the treatment (Table 2). Overall, NDW plant ${ }^{-1}$ was highly correlated to $\mathrm{NN}$ plant ${ }^{-1}$ under $\mathrm{ZS}\left(\mathrm{R}^{2}=0.86, \mathrm{P}<\right.$ $0.001)$ and $Z F\left(R^{2}=0.88, P<0.001\right)$ (Figure $4 A$ ).

In 2014, $\mathrm{NN}_{\text {plant }}{ }^{-1}$ varied significantly from $6.0 \pm 4.3$ in $\mathrm{S} 2$ to $18.6 \pm 8.2$ in $\mathrm{P} 1$ under $\mathrm{ZS}$ and from $4.2 \pm 3.9$ in $\mathrm{Z} 2$ to 24.6 \pm 4.3 in $\mathrm{S} 3$ under ZF (Fig. 3C). In comparison to ZS, the effect of $\mathrm{ZF}$ on $\mathrm{NN}$ plant ${ }^{-1}$ varied from $-77 \%$ in $\mathrm{P} 2$ to $+69 \%$ in $\mathrm{S} 3$. For each field trial, the increase of $\mathrm{NN}$ plant ${ }^{-1}$ was significant only in $\mathrm{P} 4$ and $\mathrm{S} 3$ (Fig. 3C). NN plant ${ }^{-1}$ was significantly higher in Soumyaga than in Zindiguéssé only under ZF treatment (Table 2).

NDW significantly varied from $7.9 \pm 3.4$ (S2) to $92.9 \pm 20.3$ mg NDW plant ${ }^{-1}$ in P6 under ZS and from $11.54 \pm 8,2$ in Z5 to $127,3 \pm 76,5 \mathrm{mg} \mathrm{NDW}$ plant $^{-1}$ in $\mathrm{S} 7$ under ZF (Fig. 3E). In comparison to ZS, the effect of ZF on NDW varied from $52 \%$ in $\mathrm{Z} 2$ to $+83 \%$ in $\mathrm{S} 7$. On Fig. 3E, NDW was significantly increased in 5 on 16 field trials (P4, S2, S3, S6 and S7). In Soumyaga, NDW plant ${ }^{-1}$ was significantly higher in Zindiguéssé under ZS treatment and in Pougyango under ZF treatment (Table 2). Overall and without S3 and S6, NN plant $^{-1}$ was higher correlated to NDW under $Z S\left(\mathrm{R}^{2}=0.75, \mathrm{P}\right.$ $<0.001)$ and $\mathrm{ZF}\left(\mathrm{R}^{2}=0.80, \mathrm{P}<0.001\right)$ (Fig. 4B).

\section{Plant growth}

The means of shoot dry weight (SDW plant $^{-1}$ ) per plant of cowpea was significantly increased in 2012, 2013 and 2014 by ZF compared to ZS treatment (Table 2). Whatever the treatment, SDW plant $^{-1}$ was higher in 2012 and 2014 than 2013 (Table 2).

For spatial variation in 2012, SDW plant $^{-1}$ varied significantly, under ZS treatment from $14.1 \pm 7.2(\mathrm{Z1})$ to 38.2 $\pm 13.5 \mathrm{~g} \mathrm{SDW} \mathrm{plant}^{-1}$ in $\mathrm{P} 3$, and under $\mathrm{ZF}$ treatment from 11.7 \pm 5.9 in P2 to $36.9 \pm 14.2$ g SDW plant $^{-1}$ in $\mathrm{Z2}$ (Fig. 4C). In comparison to ZS, the global effect of ZF on SDW plant ${ }^{-1}$ was significant and varied from $-61 \%$ in $\mathrm{P} 2$ to $+61 \%$ in $\mathrm{Z} 1$, though 
SDW plant $^{-1}$ only significantly increased for 2 on 12 field trials (Z1 and Z2) (Fig. 4C). SDW plant ${ }^{-1}$ was significantly
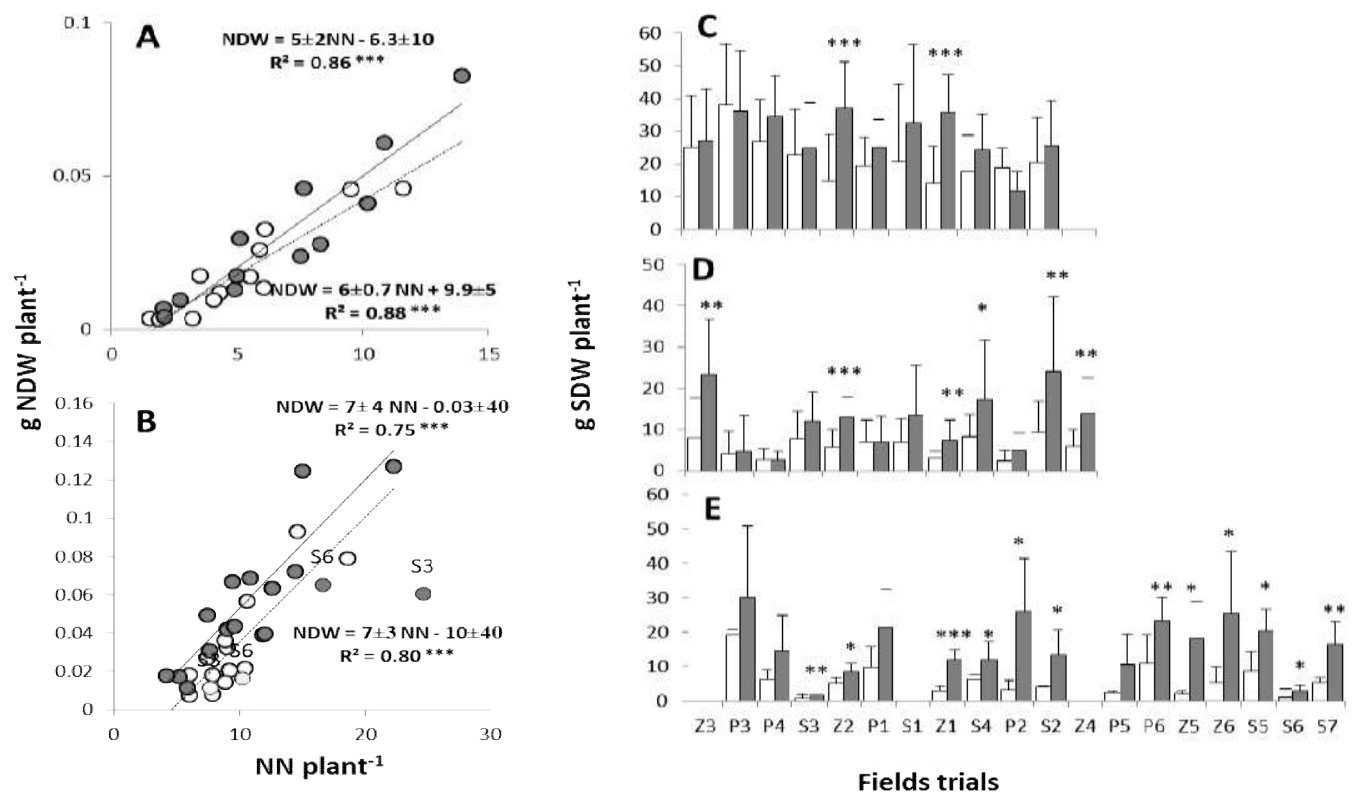

Fig. 4 Relationship nodules numbers (NN) and shoot dry weight (SDW) of cowpea plant in 2013 (A) and 2014 (B) under simple zaï $(\mathrm{O})$ and zaï + organics substrates (O). Variations of nodules dry weight (NDW) of cowpea plant in 2012 (C), 2013 (D) and 2014 (E) under simple zaï ( $\sqcup$ ) and zaï + organic substrates $(\square)$. Data are means \pm SD of 15 plants in 2012 and 2013, and 5 in 2013 by treatment respectively in 2013 and 2014 per field trials harvested at flowering stage. *,**,*** indicate that the correlations (A \& B) or the differences between means in the same field trial (C, D \& E) are significant at probability $<0.05,<0.01$ and $<0.001$, respectively according to Tukey's HSD test.

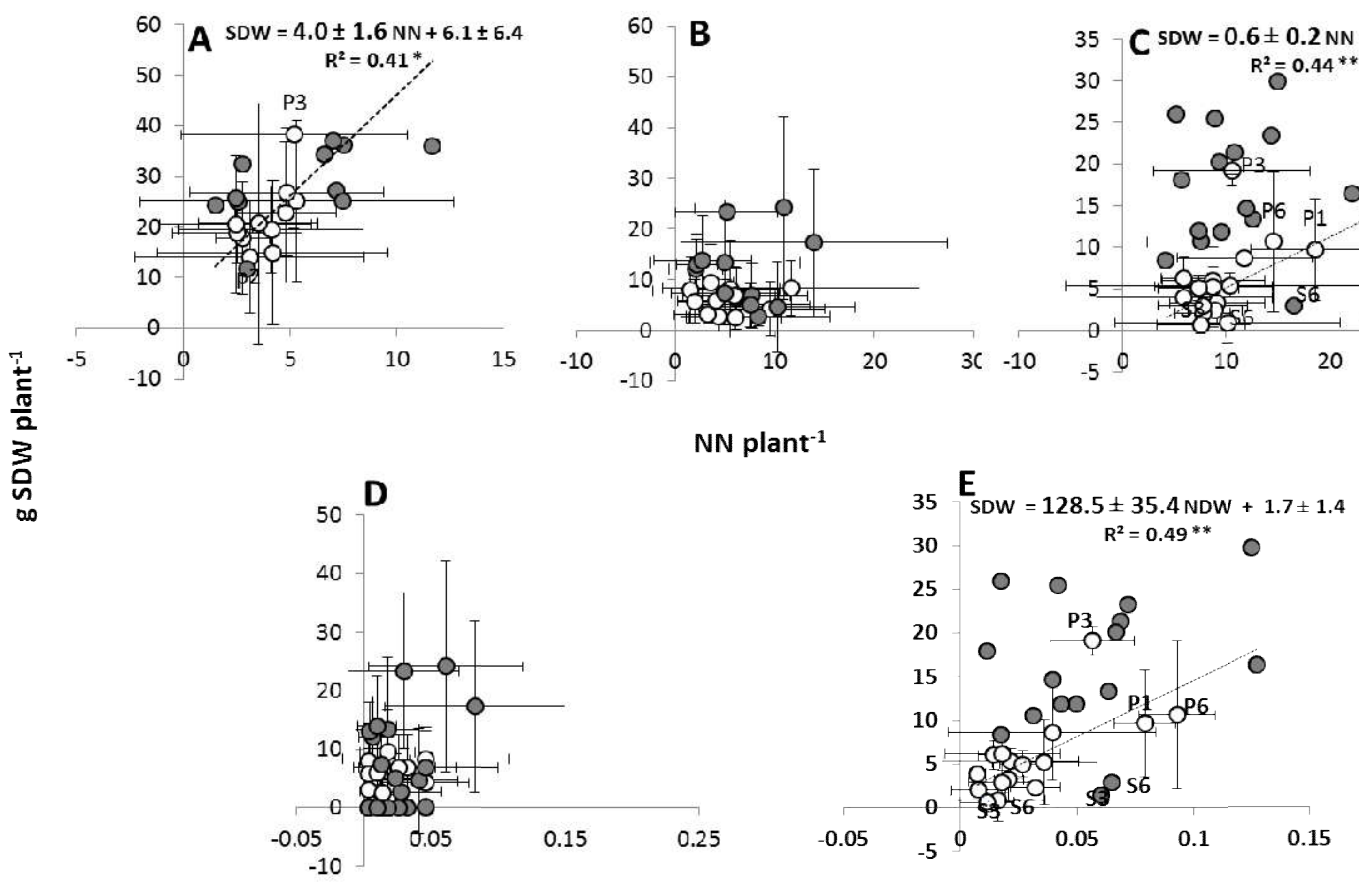

g NDW plant ${ }^{-1}$

Fig. 5 Relationship between shoot dry weight (SDW) of cowpea plant and respectively nodules number (NN) in 2012 (A), 2013 (B), 2014 ( C) and nodule dry weight (NDW) in 2013 (D), 2014 (E) under simple zaï ( $O$ ) and zaï + organic substrate ( $)$ ). Data are means \pm SD of 15 plants of cowpea in 2012, 2013 and 5 in 2014 by treatment per field trial harvested at flowering stage. *, ** indicate that the correlations between means are significant at probability $<0.05$ and $<0.01$, respectively according to Tukey's HSD test.

higher in Pougyango than Zindiguéssé and Soumyaga only under ZS treatment (Table 2).

In 2013, SDW plant ${ }^{-1}$ varied significantly, under ZS, from 2.5 \pm 2.3 in $\mathrm{P} 2$ to $9.5 \pm 7.3 \mathrm{~g} \mathrm{SDW} \mathrm{plant}^{-1} \mathrm{~g}$ in S2, and under ZF, from $2.7 \pm 1.9$ in $\mathrm{P} 4$ to $24.1 \pm 17.9 \mathrm{~g} \mathrm{SDW}$ plant $^{-1}$ in S2 (Fig.
4D). The global effect of ZF significantly increased SDW plant $^{-1}$ from +0.08 in $\mathrm{P} 1$ to $+65 \%$ in Z3, though SDW plant ${ }^{-1}$ only significantly increased for Z1, Z2, Z3, Z4, S2 and S4 (Fig. 4D). SDW plant ${ }^{-1}$ was significant higher in Soumyaga under ZS and in Soumyaga and Zindiguéssé under ZF 


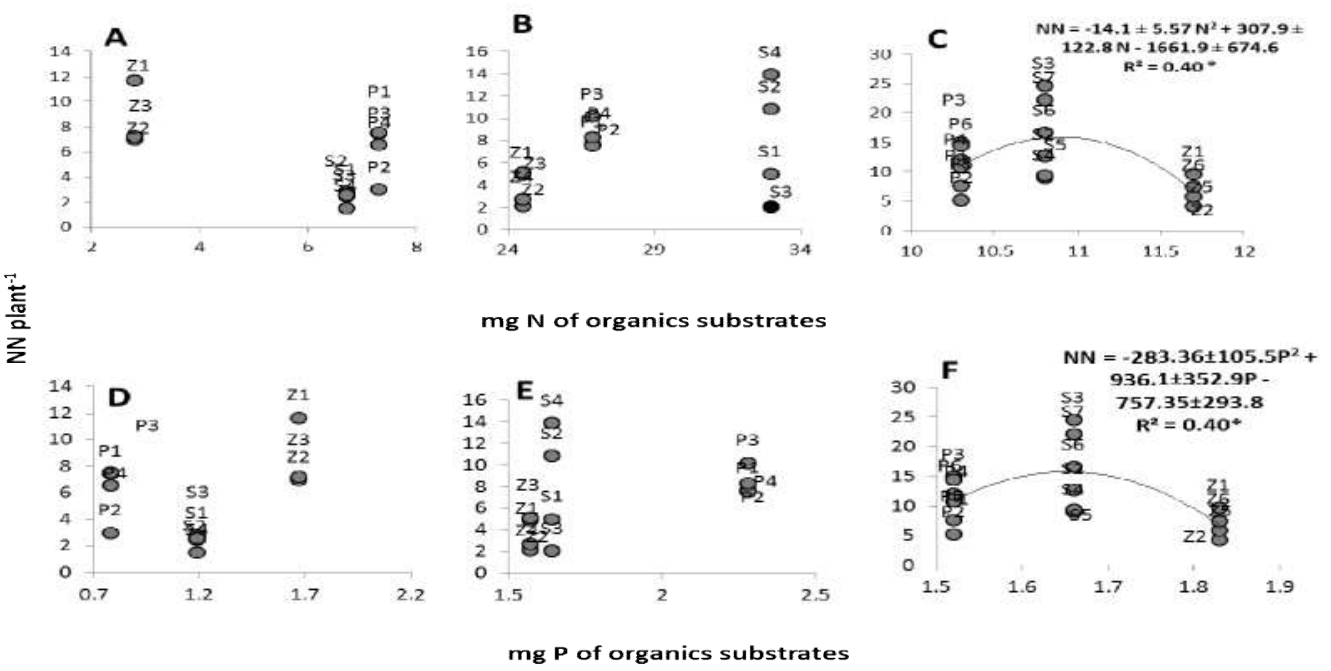

Fig. 6.Relationship between $\mathrm{N}$ of organic substrates in 2012 (A), 2013 (B) and 2014 (C) and P of organic substrates in 2012 (D), 2013 (E) and 2014 (F) and means of nodule numbers $(\mathrm{NN})$ of cowpea per field trials. * indicate that the correlations between means are significant at probability $<0.05$ according to Tukey's HSD test.

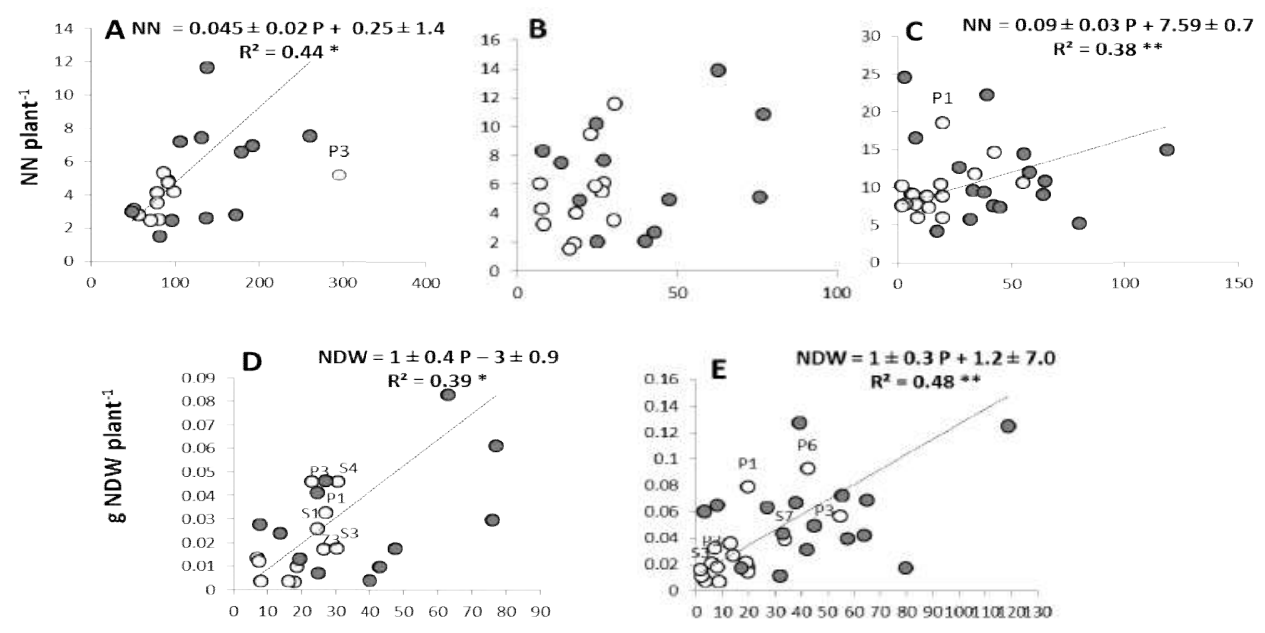

mg P g SDW plant ${ }^{-1}$

Fig. 7 Relationship between indicator P of shoot dry weight (SDW) and respectively nodules number (NN) in 2012 (A), 2013 (B) and 2014 (C) and nodules dry weight (NWD) in 2013 (D) and 2014 (E) of cowpea plant under simple zaï $(\mathrm{O})$ and zaï + organic substrates $(\mathrm{O})$. *, ** indicate that the correlations between means are significant at probability $<0.05,<0.01$ respectively according to Tukey's HSD test.

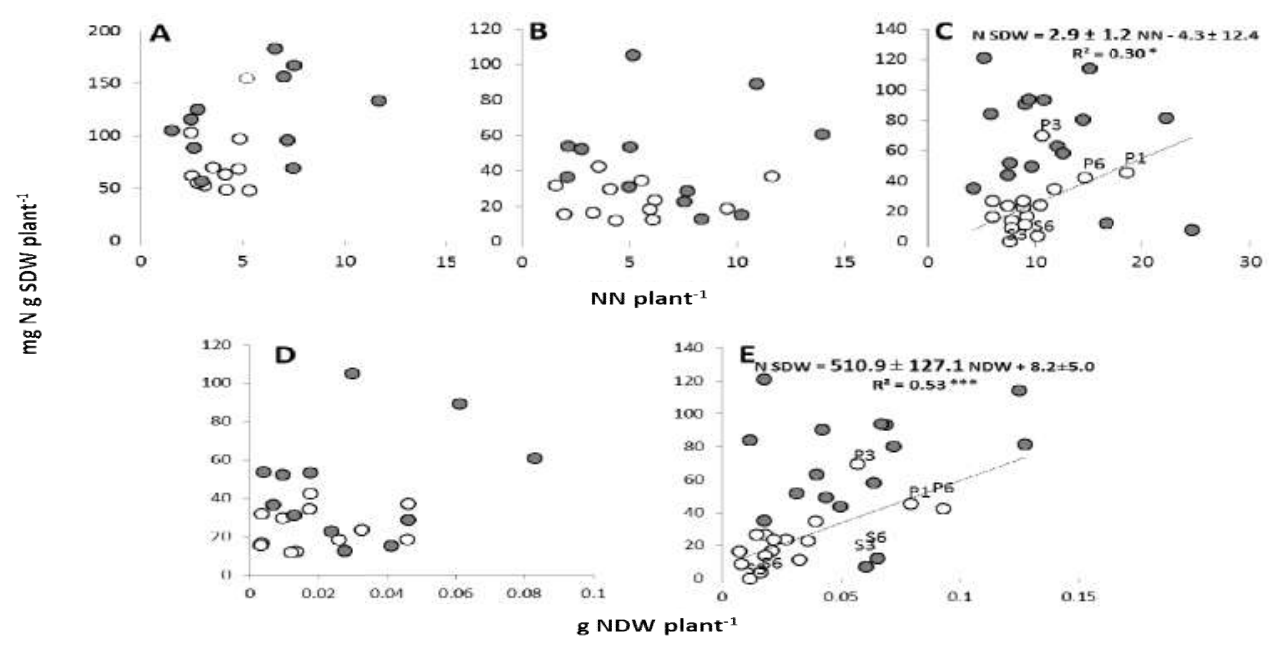

Fig. 8. Relationship between $N$ of shoot dry weight (SDW) and respectively nodules numbers (NN) in 2012 (A), 2013 (B) and 2014 (C) and nodules dry weight $(N D W)$ in $2013(C)$ and $2014(D)$ of cowpea plant under simple zaï $(\bigcirc)$ and zaï + organic substrates $(\bigcirc)$. *,**indicate that the correlations between means are significant at probability $<0.05$ and $<0.001$ respectively according to Tukey's HSD test. 
(Table 2).In 2014, SDW plant $^{-1}$ significantly varied from 0.6 \pm 0.4 in YSD to $19.1 \pm 6.1 \mathrm{~g} \mathrm{SDW} \mathrm{plant}^{-1}$ in P3 under ZS, and from $1.4 \pm 0.2$ in $\mathrm{S} 3$ to $29.9 \pm 20.9 \mathrm{~g} \mathrm{SDW}$ plant $^{-1}$ in $\mathrm{P} 3$ under $\mathrm{ZF}$

(Fig. 4E). The effect of ZF on SDW plant $^{-1}$ significantly varied from +36 in $\mathrm{P} 3$ to $+88 \%$ in $\mathrm{Z} 5$, though SDW plant ${ }^{-1}$ significantly increased in 12 on 16 field trials in Fig. 4E (P2, P6, Z1, Z2, Z5, Z6, S2, S5, S3, S6, S4 and S7). SDW plant ${ }^{-1}$ was significantly higher in Pougyango than Zindiguéssé and Soumyaga whatever the treatment (Table 2).

\section{Relation between nodulation and cowpea plant growth}

The relationship of SDW plant ${ }^{-1}$ as a function of NN was significant under ZS $\left(\mathrm{R}^{2}=0.41, \mathrm{P}<0.05\right)$ in 2012 with a regression slope, i.e. the efficiency of individual nodule to produce SDW, of $4.0 \pm 1.6 \mathrm{~g} \mathrm{SDW} \mathrm{NN}^{-1}$ (Fig. 5A). The efficiency of individual nodule to produce SDW was the highest in P3 with $6.18 \mathrm{~g} \mathrm{SDW} \mathrm{NN}^{-1}$ under ZS treatment (Fig. 5A). In 2013 and 2014, correlation between NN and SDW plant $^{-1}$ were not significant except in 2014 under ZS $\left(\mathrm{R}^{2}=\right.$ $0.45, \mathrm{P}<0.01$ ) without $\mathrm{P} 3$, with a mean efficiency of $0.6 \pm$ $0.2 \mathrm{~g} \mathrm{SDW} \mathrm{NN}^{-1}$ (Fig. 5B \& 5C).

In order to assess the effectiveness of the symbiosis for the plant growth, the mean values of SDW per treatment for each field trial were plotted as function of NDW in Fig. 5. Whatever the treatment in 2013, no significant correlation could be found between NDW and SDW plant ${ }^{-1}$ (Fig. 5C). In 2014, NDW and SDW were, globally, significantly correlated under $\mathrm{ZS}\left(\mathrm{R}^{2}=0.49, \mathrm{P}<0.01\right)$ with a value for the regressionslope, i.e. the efficiency in use of the rhizobial symbiosis (EURS) of $128.5 \pm 35.4 \mathrm{~g} \mathrm{SDW} \mathrm{g}^{-1} \mathrm{NDW}$ (Fig. 5D). Under ZS, the highest EURS was $308 \mathrm{mg} \mathrm{SDW} \mathrm{g}^{-1} \mathrm{NDW}$ in P3 field trial (Fig. 5D).

\section{Relation between $N$ and $P$ of organic substrate and nodulation}

Overall, the correlation between $\mathrm{N}$ content of organic substrates per village and means of $\mathrm{NN}$ plant ${ }^{-1}$ per field trials was not significant in 2012 and 2013 (Fig. 6A \& 6B) but only in $2014\left(\mathrm{R}^{2}=0.40, \mathrm{P}<0.05\right)$ with the regression model $\mathrm{NN}=$ $-14.1 \pm 5.6 \mathrm{~N}^{2}+307.9 \pm 122.8 \mathrm{P}-1661.9 \pm 674.6$ (Fig. 6C). Also, $\mathrm{P}$ of organic substrates was not correlated to $\mathrm{NN}$ plant ${ }^{-1}$ in 2012 and 2013 (Fig 6D \& 6E) but in $2014\left(\mathrm{R}^{2}=0.40, \mathrm{P}<\right.$ $0.05)$ with $\mathrm{NN}=-283.4 \pm 105.5 \mathrm{P}^{2}-936.1 \pm 352.9 \mathrm{P}-$ $757.3 \pm 293.8$ regression model (Fig. 6F).

\section{Relation between Soils $P$ and nodulation}

In order to assess whether the variations in nodulations among field trials sites were linked with variation in soil $\mathrm{P}$ availability, the nodulation parameters were plotted as a function of plant $\mathrm{P}$ accumulation in shoot dry weight, as an indicator of P bio-availability (Fig. 7). In 2012, soil P bioavailability and $\mathrm{NN}$ plant ${ }^{-1}$ were correlated $\left(\mathrm{R}^{2}=0.44, \mathrm{P}<\right.$ 0.05 ) only under ZS treatment, with $0.04 \pm 0.02 \mathrm{mg} \mathrm{P} \mathrm{NN}^{-1}$, without P3 field trial (Fig. 7A). In 2013, soil P bio-available was not correlated with NN whatever the treatment (Fig. 7B) but with NDW plant ${ }^{-1}\left(\mathrm{R}^{2}=0.39, \mathrm{P}<0.05\right)$ under ZS with $1 \pm$ $0.4 \mathrm{mg} \mathrm{P} \mathrm{g} \mathrm{NDW}{ }^{-1}$ (Fig. 7D). 2014, soil P bio-available and NN plant ${ }^{-1}$ was not correlated under ZF treatment but high $\mathrm{P}$ bio-available was observed in $\mathrm{P} 3$ field trial (Fig. 7C). Soil $\mathrm{P}$ bio-available was correlated $\left(\mathrm{R}^{2}=0.38, \mathrm{P}<0.01\right)$ with $\mathrm{NN}$ plant $^{-1}$ under ZS, without P1, with a mean efficiency of $0.09 \pm$
$0.03 \mathrm{mg} \mathrm{P} \mathrm{NN}{ }^{-1}$ (Fig. 7C). Soil $\mathrm{P}$ bio-available and NDW plant $^{-1}$ were correlated $\left(\mathrm{R}^{2}=0.48, \mathrm{P}<0.01\right)$ with a means efficiency of $1 \pm 0.3 \mathrm{mg} \mathrm{P} \mathrm{g} \mathrm{NDW}^{-1}$ (Fig. 7E).

\section{Efficiency of $N$ derived from atmosphere}

In 2012 and 2013, any correlation was observed between NN or NDW and $\mathrm{N}$ g SDW plant ${ }^{-1}$ (Fig. 8A, 8B \& 8D). NN and $\mathrm{mg} \mathrm{N}_{\mathrm{g} \text { SDW }}$ plant $^{-1}$ were significantly correlated under ZS $\left(\mathrm{R}^{2}=0.30, \mathrm{P}<0.05\right)$ with efficiency of 1 nodule to produce $2.9 \pm 1.2 \mathrm{mg} \mathrm{N} \mathrm{g} \mathrm{SDW}^{-1}$ only in 2014 (Fig. 8C). During the same year, mg NDW and $\mathrm{N}$ accumulated in SDW plant ${ }^{-1}$ were significantly correlated under $\mathrm{ZS}\left(\mathrm{R}^{2}=0.53, \mathrm{P}<0.001\right)$ with efficiency of Ndfa of $510.9 \pm 127.1 \mathrm{mg} \mathrm{N}$ fixed $\mathrm{g} \mathrm{NDW}^{-1}$ (Fig. 8E). The highest efficiency of $1085.2 \mathrm{mg} \mathrm{N} \mathrm{g} \mathrm{NDW}^{-1}$ was observed in P3 field trial and the lowest in S3 and S6 field trials with -711.9 and $-282.8 \mathrm{mg} \mathrm{N}$ g SDW $\mathrm{g} \mathrm{NDW}^{-1}$ respectively (Fig 8E).

\section{DISCUSSION}

The major result of our work is the large spatial and temporal variation of cowpea nodulation and response to organic substrates in the Sub-Saharan agro-ecosystem of Burkina Faso (Figures $3 \& 4$ ). To our knowledge, this spatial and temporal variability has not been described previously using such an extensive data collection in farmers' fields. The interannual variability may be explained by variation of the average rainfall per year. Thus, the low dry weight of nodules and shoots in 2013, whatever the treatment, could be explained by the $20 \%$ lower average rainfall in 2013 than in 2012 and 2014 (Fig. 2A). Similarly, the low rainfall is likely to explain the poor nodulation of soybean in central Kenya (Herrmann et al. (2013). Excess of water may also be detrimental like in Z4 (Fig. 3A) where cowpea could not be harvested in 2012, because of waterlogging in zaï bowl before flowering. The low water infiltration was observed after successive strong rain. It caused the rotting of cowpea plants in the cotylodenary node confirming that cowpea does not tolerate the soil long waterlogging (Hong et al., 1977).

The differences between villages for nodulation and plant growth could be explained by a decreasing rainfall gradient from Pougyango to Soumyaga, and its interactions with soil and organics substrates. Also, the variability in responses of nodulation and cowpea growth to treatments suggests fieldspecific interactions between treatment and rhizosphere conditions. Thus in Brazil, the biomass production of cowpea 37 days after sowing was higher in an Anthrosol than a Ferralsol, both amended with poultry manure (Lehmann et al., 2003).

Within the fertilized treatment, the relationship between $\mathrm{N}$ or $\mathrm{P}$ content of organic substrates in 2014 and $\mathrm{NN}$ of cowpea (Fig. 6C \& 6F) could reflect a beneficial effect of $\mathrm{N}$ and $\mathrm{P}$ fertilization on rhizobia infectivity under normal water conditions, by contrast with 2013 when the year was less rainy. In 2012 under ZS, NN variability (Fig. 7A) could be explained by the variation of P bio-availability except in P3. In 2013 and 2014 under ZS, the relation between NDW and soil P bio-availability (Fig. 7D \& 7E) confirm the later to be an important factor for number and weight of nodules of cowpea. Thus, the use of 20, 40, 80 and $160 \mathrm{~kg} \mathrm{ha}^{-1}$ of $\mathrm{P}_{2} \mathrm{O}_{5}$ derived from single super phosphate produced higher relative efficiency for nodulation and biological nitrogen fixation of 
cowpea in greenhouse using pots experiment (Silva et al., 2010). Increasing phosphorus levels from 30 to $120 \mathrm{~kg} \mathrm{P}_{2} \mathrm{O}_{5}$ $\mathrm{ha}^{-1}$ in sandy clay loam soil of Ghana that initially contained $108 \mathrm{mg} \mathrm{P} \mathrm{kg}^{-1}$ and $1.33 \mathrm{~g} \mathrm{~N} \mathrm{~kg}^{-1}$ increased the cowpea $\mathrm{NN}$ and the $\mathrm{N}$ and $\mathrm{P}$ contents in the dry matter at harvest (Assuming-Brempong et al., 2013). These may be attributed to phosphorus stimulation of root and plant growths before nodule formation since higher availability of $\mathrm{P}$ may stimulate nodulation due to the transfer of energy in form of ATP, and contribute to increase root hair formation and to provide more sites for rhizobia infection of cowpea (Okeleye and Okelana, 1997). The higher NN and NDW, and shoot dry weight (Table 2) of cowpea under ZF than ZS suggests a positive effect of mineralized $\mathrm{P}$ from organic fertilizers on the formation and functioning of nodules, whereas mineralized $\mathrm{N}$ did not limit nodulation. In this respect, input of $26 \mathrm{~kg} \mathrm{~N} \mathrm{ha}^{-1}$ on humic nitosols that initially had $20 \%$ of $\mathrm{N}$, did not affect the NN and NDW of cowpea (Chemining'wa et al., 2007). Also, the capacity of organic substrates to stimulate specifically some populations of arbuscular mycorrhizal fungi of soils could increase nutrient uptake for plants growth (Sharpley and Moyer, 2000; Muthukumar and Udaiyan, 2002)

In 2013, the low rainfall could explain the absence of any correlation between NN or NDW and SDW of cowpea (Fig. 5B \& 5D) since water deficit has a negative effect on cowpea nodulation (Zahran, 1999), and its nitrogen fixation can decrease by $75 \%$ through nodules detachment (Zablotowicz et al., 1981). In 2014 under ZS, the high EURS of $128.5 \pm 35.4 \mathrm{~g}$ SDW g ${ }^{-1}$ NDW (Fig. 5E) suggests that shoot dry weight depends on nodulation and nitrogen fixation activity of nodules in conditions of low availability of soil nitrogen. This high EURS is confirmed by the estimate of $510.9 \pm 127.1 \mathrm{mg}$ $\mathrm{N} \mathrm{g}^{-1} \mathrm{NDW}$ for the $\mathrm{N}$ derived from nodule $\mathrm{N}_{2}$ fixation (Fig. $8 \mathrm{E})$. At low levels of mineral-N, cowpea was recorded to fix from 64 to $134 \mathrm{~kg} \mathrm{~N} \mathrm{ha}^{-1}$ in Northern-Ghana (Dakora et al., 1987) and up to $52 \mathrm{~kg} \mathrm{~N} \mathrm{ha}^{-1}$ in Nigeria as intercropped with maize (Egbe and Egbo, 2011). The high efficiency of individual nodule to produce SDW in 2012 (Fig. 5A), and in 2014 the higher EURS in P3 (Fig. 5E) under ZS, than in other field may be explained by the high initial value of bioavailable $\mathrm{P}$ in this field trial. Contrary, the lowest values of EUSR and $\mathrm{N}$ accumulation in shoot dry weight in S3 and S6 field-trials in 2014 whatever the treatment (Fig. 5C \& 8E) may be explained by the absence of weeding in these fields since competition from the natural weed flora may affect the number of days to $50 \%$ flowering and growth of cowpea (Remisona, 2009).

\section{CONCLUSIONS}

Nodulation of cowpea under zaï cultivation in Sub-Saharan agro-ecosystem of Burkina Faso varies spatially and temporally. This highlights the interest to conduct studies in several fields over several years. Temporal variation may be due to the variability of average rainfall per year. Whatever the year, nodulation and plant growth in our study were increased by organic fertilization compared to simple zaï. Spatial variability of nodules numbers may be related to $\mathrm{N}$ and $\mathrm{P}$ contents of fertilizers according to years, whereas under simple zaï, nodule dry weight varied with soil $\mathrm{P}$ bioavailability. Soil waterlogging and the absence of weeding also explained some differences of cowpea nodulation between fields whatever the treatment. The efficiency in use of the rhizobial symbiosis was achieved under simple zaï in 2014 with high $\mathrm{N}$ derived from nodule $\mathrm{N}_{2}$ fixation for cowpea plant growth. Our nodular diagnosis should help to draw practical recommendations for nodulation in cowpea-sorghum intercropping and identify specific field-responses in order to improve both crops yields and soils fertility in NorthernBurkina. Thus, more work is needed on soil chemical, physical and biological characteristics, in order to assess their contributions to the observed spatial variations of nodulation and the subsequent growth of cowpea intercropped with sorghum in this region.

\section{Acknowledgements}

The Great Federative Project of Agropolis named FABATROPIMED under the reference ID 1001-009, and IRD (LMI-IESOLS) supported this work.

\section{References}

Asuming-Brempong, S., Wiafe, Y. and Aggrey, M.K. (2013): Nodulation of cowpea (Vigna unguiculata $[L]$ walp) at different levels of phosphorus in a Typic Kandiustalf. Agri. Sci. Res. J., 3: 387- 394.

Bado, B.V., Bationo, A. and Cescas M.P. (2006): Assessment of cowpea and groundnut contributions to soil fertility and succeeding sorghum yields in the Guinean savannah zone of Burkina Faso (West Africa). Biol. Fertil. Soils, 43: 171-176.

Bationo, A. and Ntare, B.R. (2000): Rotation and nitrogen fertilizer effects on pearl millet, cowpea, and groundnut yield and soil chemical properties in a sandy soil in the semi-arid tropics, West Africa. J. Agr. Sci., 134: $277-$ 284.

Bationo, A., Ntare, B.R., Tarawali, S.A. and Tabo R. (2002): Soil fertility management and cowpea production in the semiarid tropics. In Fatokun C. A. (eds), Challenges and Opportunities for Enhancing Sustainable Cowpea Production, pp: 300-318.

Bayala, J., Sileshi, G.W., Coe, R., Kalinganire, A., Tchoundjeu, Z., Sinclair, F. and Garrity, D. (2012): Cereal yield response to conservation agriculture practices in drylands of West Africa: A quantitative synthesis. J. Arid. Environ., 78: 13-25.

Chemining'wa, G.N., Muthomi, J.W. and Theuri, S.W. M. (2007): Effect of rhizobia inoculation and Starter-N on Nodulation, shoot biomass and yield and grain legumes. Asian J. Plant Sci., 6: 1113-1118.

Dakora, F.D., Aboyinga, R.A., Mahama, Y. and Alesaku, J. (1987): Assessment of $\mathrm{N}_{2}$ fixation of legumes in groundnut (Arachis hypogea L.) and cowpea (Vigna unguiculata L.Walp.) and their relative $\mathrm{N}$ contribution to a succeeding maize crop in northern Ghana. Mircen. J. Appl. Microb., 3: 389-399.

de Freitas, A.D.S, Silva, A.F. and de Sa Barretto Sampaio, E.V. (2012): Yield and biological nitrogen fixation of cowpea varieties in the semi-arid region of Brazil. Biomass. Bioenerg., 25: 109-114.

Egbe, M.O., Alhassan, G.A. and Ijoyah, M. (2010): Nodulation, nitrogen yield and fixation by Bambara groundnut (Vigna Subterranea (L.) Verdc.) landraces 
intercropped with cowpea and maize in Southern Guinea savanna of Nigeria. Agri. Sci., 1: 15-28.

Egbe, O.M. and Egbo, C.U. (2011): Nodulation, nitrogen fixation and harvest index of extra-short-and shortduration cowpea varieties intercropped with maize at Otobi, Benue state, Nigeria. J. Anim. Plant Sci., 10: 1315-1324.

Fustec, J., Fabien, L., Mahieu, S. and Cliquet, J.B. (2011) : Rhizodéposition azote des légumineuses. Volume agriculture durable 2; partie 7, pp: 869-881.

Hien, E., Kaboré, W.T., Masse, D. and Dugué P. (2010): Sustainable farming systems in the sub-sahelian zone of Burkina Faso-Key Factors. Sustainability in Debate (Special Issue Climate, Sustainability and Development in Semi-Arid Regions), 1:127-140.

FAO, Food and Agriculture Organization (2000) : La Base de données mondiale sur les sols: avantages et faiblesses pour la connaissance et l'utilisation des milieux édaphiques au Burkina Faso. In Quatorzième réunion du sous-comité ouest et centre africain de corrélation des sols pour la mise en valeur des terres. Abomey, Benin, 9-13 Octobre 2000, pp. 121-128.

FAO, Food and Agriculture Organization (2014): IUSS Working Group WRB. 2014. World Reference Base for Soil Resources 2014. International soil classification system for naming soils and creating legends for soil maps. World Soil Resources Reports, 106. FAO, Rome. 191p. http://www.fao.org/3/a-i3794e.pdf. Accessed 16 April 2015.

Guinko, S. (1998): Caractéristiques de la végétation du Burkina Faso et leurs impacts sur les sols. 16ème Congrès Mondial de science du sol. Ouagadougou, Burkina Faso. 13 p.

Herrmanna, L., Chotte, J.L., Thuita, M. and Lesueura, D. (2013): Effects of cropping systems, maize residues application and $\mathrm{N}$ fertilization on promiscuous soybean yields and diversity of native rhizobia in Central Kenya. Ped J Soil Ecol 57: 75-85.

Kitson, R. E., Mellon, M. G. (1944): Colorimetric Determination of Phosphorus as Molybdivanadophosphoric Acid. Ind. Eng. Chem. Anal. Ed., 16: 379-383.

Hong, T.D., Minchin, F.R. and Summerfield, R.J. (1977): Recovery of modulated cowpea plants (Vigna Unguiculata (L.) Walp.) from waterlogging during vegetative growth. Plant Soil, 48: 661-672.

Kouyaté, Z., Krasova-Wade, T., Yattara, I.I. and Neyra M. (2014): Effects of cropping system and Cowpea variety (Vigna unguiculata L. Walp) on the diversity of native cowpea bradyrhizobia and millet yield in the Sudano Sahelian zone of Mali. Int. Res. J. Agri. Sci. Soil Sci., 4: 30-39.

Laberge, G., Haussmann, B.I.G., Ambus, P. and Jensen, H.H. (2011): Cowpea N rhizodeposition and its belowground transfer to a co-existing and to a subsequent millet crop on a sandy soil of the Sudano-Sahelian ecozone. Plant Soil, 340: 369-382.

Lehmann, J., Pereira da Silva, J. Jr., Steiner, C., Nehls, T., Zech, W. and Glaser, B. (2003): Nutrient availability and leaching in an archaeological Anthrosol and a Ferralsol of the Central Amazon basin: fertilizer, manure and charcoal amendments. Plant Soil, 249: 343-357.
Muthukumar, T. and Udaiyan, K. (2002): Growth and yield of cowpea as influenced by changes in arbuscular mycorrhiza in response to organic manuring. J. Agron. Crop Sci., 188: 123-132.

Oroka, F.O. (2010): Responses of rice and cowpea intercropping to nitrogen fertilizer and plant population: Nodulation, Nitrogen Fixation and Agronomic Efficiency. World J. Agri. Sci., 6: 154-159.

Okeleye, K.A. and Okelana, M.A. (1997): Effect of phosphorus fertilizer on nodulation, growth and yield of cowpea (Vigna unguiculata) varieties. Indian J. Agri. Sci., 67: 10-12.

Remisona, S.U. (2009): The performance of cowpea (Vigna unguiculata (L.) Walp) as influenced by weed competition. J. Agri. Sci., 90: 523-530.

Roose, E. (2004) : La gestion conservatoire de l'eau et de la fertilité des sols : une stratégie nouvelle de la lutte antiérosive pour le développement durable. Sécheresse,

15: 5-7.

Santos J.A., Nunes, L.A.P.L., de Melo, W.J., do Vale Figueiredo, M.B., Singh, R.P., Bezerra, A.A.C. and de Araújo, A.S.F. (2011): Growth, nodulation and nitrogen fixation of cowpea in soils amended with composted tannery sludge. R. Bras. Ci. Solo., 35:18651871.

Sharpley, A.N. and Moyer, B. (2000): Phosphorus forms in manure and compost and their release during simulated rainfall. J. Environ. Quai., 29: 1462-1469.

Sawadogo, H., Bock, L., Lacroix, D. and Zombré, N.P. (2008) : Restauration des potentialités de sols dégradés à l'aide du zaï et du compost dans le Yatenga (Burkina Faso). Biotechnol. Agron. Soc. Environ., 12: 279-290.

Silva, L., Freitas, E., de Araujo, F., Sergio, A., Santos, D., Valdinar B. et al. (2010): Biological n-2 fixation in cowpea under different rates and sources of soluble phosphorus. Biosc. J., 26 : 394-402.

Singh, B. and Usha, K. (2003): Nodulation and symbiotic nitrogen fixation of cowpea genotypes as affected by fertilizer nitrogen. J. Plant Nutr., 26: 463-473.

Somé, D., Hien, E., Assigbetse, K., Drevon, J.J. and Masse, D. (2015) : Dynamique des compartiments du carbone et de l'azote dans le sol cultivé en niébé et sorgho dans le système zaï en zone Nord soudanienne du Burkina Faso. Int. J. Biol. Chem. Sci., 9: 954-969.

Zablotowicz, R.M., Focht, D.D. and Cannell, G.H. (1981): Nodulation and $\mathrm{N}$ fixation of field-grown california cowpeas as influenced by well-irrigated and droughted conditions. Agron. J. 73:9-12.

Zahran, H.H. (1999): Rhizobium-legume symbiosis and nitrogen fixation under severe conditions and in an arid climate. Microbiol. Mol. Biol. Rev., 63: 968-989.

Zougmoré, R., Ouattara K., Mando, A. and Ouattara, B. (2004): Rôle des nutriments dans le succès des techniques de conservation des eaux et des sols (cordons pierreux, bandes enherbées, zaï et demi-lunes) au Burkina Faso. Sciences et changements planétaires/Sécheresse, 15:41-48. 